\title{
LUT
}

University

\section{The Role and Impact of Descriptive Theories in Creating Knowledge in Design Science}

\author{
Knutas Antti, Pourzolfaghar Zohreh, Helfert Markus
}

This is a Post-print

version of a publication

published by Springer Cham

in Holzinger A., Silva H., Helfert M. (eds) Computer-Human Interaction Research and Applications. CHIRA 2017. Communications in Computer and Information Science, vol 654.

DOI: 10.1007/978-3-030-32965-5_5

Copyright of the original publication: () Springer Nature Switzerland AG 2019

Please cite the publication as follows:

Knutas, A., Pourzolfaghar, Z., Helfert, M. (2019). The Role and Impact of Descriptive Theories in Creating Knowledge in Design Science. In: Holzinger, A., Silva, H., Helfert, M. (eds) ComputerHuman Interaction Research and Applications. CHIRA 2017. Communications in Computer and Information Science, vol. 654. Springer, Cham. pp. 90-108. DOI: https://doi. org/10.1007/978-3-030-32965-5_5

This is a parallel published version of an original publication. This version can differ from the original published article. 


\title{
The Role and Impact of Descriptive Theories in Creating Knowledge in Design Science
}

\author{
Antti Knutas ${ }^{10000-0002-6953-0021]}, Z^{2}$ ohreh Pourzolfaghar ${ }^{2}$ and Markus Helfert ${ }^{2[0000-0001-6546-}$ \\ 6408] \\ ${ }^{1}$ Lero, the Irish Software Research Centre, Glasnevin, Dublin 9, Ireland \\ ${ }^{2}$ Dublin City University, Glasnevin, Dublin 9, Ireland \\ antti.knutaselut.fi
}

\begin{abstract}
In this paper, we clarify the role of descriptive knowledge in creating prescriptive knowledge with design science research. We demonstrate the connection by presenting an approach that utilizes kernel theories produced by the grounded theory research methodology in the creation of meta-level design science artefacts. These meta-level artefacts can be used to inform the design processes of situational artefacts, such instantiations of software and services. We demonstrate and evaluate the approach further by using it to frame an ongoing research project that creates a meta-artefact to address issues in smart city service design.
\end{abstract}

Keywords: Design science, kernel theory, grounded theory, descriptive knowledge, prescriptive knowledge, meta-artefact.

\section{$1 \quad$ Introduction}

Design science research (DSR) at its core is the science of the artificial, involving scientifically rigorous creation of artefacts that have utility in an application domain and at the same contribute to the scientific body of knowledge [1,2]. What is different in design science research from positivist research, is that a final outcome in design science research is prescriptive knowledge [3]. Design science research often begins with an important opportunity, challenging problem or a vision for the application domain $[3,4]$. During the research process DSR produces both an artefact that addresses an issue in the application domain, and also prescriptive knowledge on how to change things [3]. In addition to instantiations of artefacts, design science processes can create higher level of artefacts such as design methods, principles, or theories. In natural and social sciences, a theory is likely to be seen as explaining and predicting a phenomenon [5]. Its nature is descriptive. Design science draws from a constructivist background and its main results are prescriptive [3]. Design theories as prescriptive knowledge are different from positivist, descriptive theories in the sense that a design theory does not only model, but also prescribes ways to act. Essentially a design theory gives prescriptions for design and action: it tells how to do something $[3,6]$.

Before a phenomenon or a situation can be changed, it is necessary to understand it in depth. Descriptive knowledge that explains a phenomenon is called justificatory 
knowledge [5] or a kernel theory [3]. The kernel theory that is used as a basis for artefact creation can also be tested and refined during the design science research process [7]. Ostrowski and Helfert [8-11] presented a design science research framework which follows Goldkuhl and Lind's [12] division of design science research into a situational, empirical part (design practice) and abstract, design knowledge part (meta-design). The meta-design part is informed by descriptive theory, and the empirical part is in turn informed by the abstract design knowledge created in the metadesign process. In essence, the meta-design process creates a meta-artefact that guides situational design practice that occurs in a specific context $[8,12]$. The meta-artefact provides more general design knowledge, is not situated in any specific context, and requires adaptation for a specific situation by the design science practitioner [12]. The approach by Ostrowski and Helfert uses business process modeling, engagement with practitioners, and literature reviews to create the justificatory knowledge as a basis for the design science research process and is most suitable for situations where it is possible to capture explicit organizational knowledge.

In this paper, we extend the original framework by Ostrowski et al. [8-11] and present an approach that uses grounded theory -based kernel theories as a basis for creating design science artefacts. The main novel contribution in this paper is using the approach to demonstrate and explain the bidirectional connection between the kernel theories and design science research processes. We also show how the evaluation part of the design process contributes to grounded kernel theory through constant comparison and grounding the kernel theory back to the data [13], which allows further development of the kernel theory when interacting with the application domain. Grounding, or connecting the research process to external knowledge, is essential in both grounded theory [14] and design science research $[1,12]$. The main difference is that according to the principles of the grounded theory method, grounded theories are grounded back only to the empirical data [15]. By contrast, design science research methodology can include a more complex interplay of grounding processes between theories, artefacts, the body of scientific knowledge, and the application domain [12].

Compared to process modeling, grounded theory is more suitable for describing complex situations with human factors that are challenging to address with formal models [15]. Therefore, the approach presented in this paper is especially suited for socio-technical systems where the knowledge is tacit instead of formal, which is often the case in human societies and multi-stakeholder environments.

To demonstrate our approach for integrating grounded theory in creating abstract design knowledge we present an ongoing research case, originally introduced in [16, 17], on creating a taxonomy for informing smart city service design processes. This process was initiated by the observation that requirements engineering processes, as they exist in smart city service design today, need guidance. A taxonomy of concepts essential to service design would enable service developers to align requirements with the citizens' needs in a smart city context. However, how to ensure that the taxonomy responds to the needs of the application domain, is valid and is scientifically rigorous?

We summarize the research goals of this paper as follows. 
1. Clarify the bidirectional connection between kernel theories and design science processes. This is accomplished by presenting an approach that utilizes grounded theory to generate kernel theories as an input for Ostrowski and Helfert's metalevel design science process [8-11].

2. Demonstrate the novel approach by presenting a case where a design science research process is used to create a meta-level artefact in the form of a taxonomy of smart city elements.

The rest of the paper is structured as follows. In Section two review the design science research approach and in Section three we review the grounded theory research method. In section four we present our approach to connect the generation of descriptive knowledge to design science processes. In Section five we evaluate the approach by using it to frame an ongoing research project. The paper ends with Section six, conclusion.

\section{Design Science Research Approach}

The overall research approach for this paper is design science [1], which is commonly used in the information system sciences to create artefacts in the form of instantiated systems or new design knowledge [3]. Hevner and Chatterjee [18, p. 5] define design science research as follows:

"Design science research is a research paradigm in which a designer answers questions relevant to human problems via the creation of innovative artifacts, thereby contributing new knowledge to the body of scientific evidence. The designed artifacts are both useful and fundamental in understanding that problem."

From the above, Hevner and Chatterjee [18, p. 5] derive the first principle of DSR: "The fundamental principle of design science research is that knowledge and understanding of a design problem and its solution are required in the building and application of an artefact." What essentially separates the design science research process from routine design practice is the creation of new knowledge [1]. If the design process is rigorous, it is based on existing theories and produces new scientific knowledge, then the process can be considered design science research.

Design science research is well applicable in situations where humans and software systems intersect [18], like information systems research. What makes information systems research unique is that it investigates the phenomenon where technological and social systems intersect [19] in the form of socio-technical systems, which requires a research methodology that takes both into account.

The concept of an artefact is at the core of the research science process. In a synthesis of the Sciences of the Artificial [20] and Developing a Discipline of the Design/Science/Research [21] by Hevner and Chatterjee [18], they broadly define artefacts, which are the end-goal of any design science research project, as follows: Con- 
struct (vocabulary and symbols), models (abstractions and representations), methods (algorithms and practices), instantiations (implemented and prototype systems), and better design theories. Gregor and Hevner [3] further divide design science research outputs into three maturity levels, with level one being most situational and level three being most abstract. This progression also follows the produced research knowledge's maturity level, or how far has the contribution has advanced in terms of the characteristics of a well-developed body of knowledge [3]. This categorization is presented in Table 1.

Table 1. Design science research contribution types by Gregor and Hevner [3]

\begin{tabular}{|l|l|l|}
\hline & Contribution type & Example artefact \\
\hline $\begin{array}{l}\text { More abstract, complete, and } \\
\text { mature knowledge }\end{array}$ & $\begin{array}{l}\text { Level 3. Well-developed } \\
\text { design theory about embed- } \\
\text { ded phenomena }\end{array}$ & $\begin{array}{l}\text { Design theories (mid-range } \\
\text { and grand theories) }\end{array}$ \\
\cline { 2 - 3 } & $\begin{array}{l}\text { Level 2. Nascent design } \\
\text { theory-knowledge as opera- } \\
\text { tional principles/architecture }\end{array}$ & $\begin{array}{l}\text { Constructs, methods, models, } \\
\text { design principles, technologi- } \\
\text { cal rules. }\end{array}$ \\
\cline { 2 - 3 } $\begin{array}{l}\text { More specific, limited, and } \\
\text { less mature knowledge }\end{array}$ & $\begin{array}{l}\text { Level 1. Situated implemen- } \\
\text { tation of artefact }\end{array}$ & $\begin{array}{l}\text { Instantiations (software prod- } \\
\text { ucts or implemented process- } \\
\text { es) }\end{array}$ \\
\hline
\end{tabular}

The seminal paper by Hevner et al. [1] on design science in information systems research does not present a model or process for performing design science research. However, a later paper [2] refines the concept further and identifies the existence of three design science cycles that are present in all design research projects. These cycles are the Relevance Cycle, which connects the contextual environment to the research science project, the Rigor Cycle, which connects the design activities to the knowledge base of scientific foundations, and the Design Cycle which iteratively connects the core activities of building a design artefact and research.

Hevner's three cycle view clarified the elements of design science research, but it still didn't provide systematic steps for conducting it. To provide a process model Peffers et al. [22] synthesized a design science research methodology from the evolving body of knowledge on design science. The process contains six activities, which are summarized as follows: Problem identification and motivation, defining the objects for a solution, design and development, demonstration, evaluation and communication.

\subsection{Creating Meta-Level Artefacts}

In this section, we describe the abstract design knowledge framework by Ostrowski and Helfert [8-11], which follows Goldkuhl and Lind's [12, 23] division of design science research into an empirical part (a design practice) and a theoretical part (metadesign). Their design knowledge framework presents a process for creating metaartefacts, which consist of abstract design knowledge. These meta-artefacts in turn can be used in the creation of situational design knowledge, such as instantiations of IT systems. The different artefact types introduced by Hevner et al. [1, 3] are divided 
by Goldkuhl and Lind [12] into situational and abstract, instead of by the level of maturity. This alternative categorization is presented in Table 2.

Table 2. Design science research artefacts differentiated into abstract and situational [12]

\begin{tabular}{|l|l|l|}
\hline Activity type and outcome & $\begin{array}{l}\text { From meta-design: Abstract } \\
\text { design knowledge }\end{array}$ & $\begin{array}{l}\text { From design practice: Sit- } \\
\text { uational design knowledge } \\
\text { and results }\end{array}$ \\
\hline Constructs & Abstract concepts & $\begin{array}{l}\text { Situational concepts (may be } \\
\text { applied and adapted from } \\
\text { abstract concepts) }\end{array}$ \\
\hline Models & Generic models & Situational models \\
\hline Methods & $\begin{array}{l}\text { Guidelines for design prac- } \\
\text { tice }\end{array}$ & $\begin{array}{l}\text { Parts of a situational system } \\
\text { or process }\end{array}$ \\
\hline Instantiations & $\begin{array}{l}\text { (System abstraction with key } \\
\text { properties) }\end{array}$ & $\begin{array}{l}\text { IT systems } \\
\text { (prototype or working sys- } \\
\text { tem) }\end{array}$ \\
\hline
\end{tabular}

Abstract meta-design artefacts can be used as 1) a preparatory activity before situational design is started, 2) a continual activity partially integrated with the design practice, or 3) a concluding theoretical activity summarizing, evaluating and abstracting results directed for target groups outside the studied design and use practices [12]. These types of meta-artefacts are general, abstract and apply to "unreal situations" $[24,25]$. However, meta-design produces solid basis for design science activities to construct solutions for real environments, systems and people $[9,12]$.

Ostrowski and Helfert [9] extended Peffers's design science research process [22] to include the split of design knowledge into abstract and situational [12], and the split of evaluation into naturalistic and artificial $[25,26]$. The process created by Ostrowski and Helfert is presented in Figure 1. They further divide the meta-artefact design process into three steps that interact with each other: Modelling, literature review and engagement scholarship $[9,10]$.

In the abstract design knowledge phase two levels of knowledge, literature and design experts, contribute to create reference models for design [10]. Literature review allows developing an initial scope and reviewing existing knowledge, and collaboration with practitioners allows ensuring problem relevancy and gaining current design knowledge. These two information sources are combined to a reference model, which allows modelling and evaluation of solutions $[8,10]$. This model is then compared to existing body of knowledge as theoretical grounding in a rigor cycle, and to designers for the design practice phrase in a meta-relevance cycle [10].

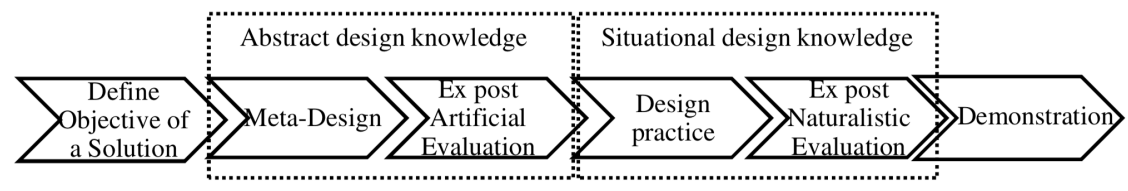


Fig. 1. The design science research method process [22] extended by Ostrowski and Helfert to include the meta-design step [9]

In Figure 2 we extend Hevner's three cycle view [2] to include the split between abstract and situational knowledge according to ideas presented by Ostrowski and Helfert [9]. The original three cycle view included only the top half. In the extended view the top level contains the application environment and situational design. The lower level contains the creation of abstract design knowledge, which informs and guides the design of situational artefacts.

The lower half of the Figure 2 presents how both design experts and the body knowledge contribute to the creation of new meta-artefact. Literature review allows developing an initial scope for the solution from existing knowledge. Collaboration with practitioners allows ensuring problem relevancy and benefits from their applied design knowledge. This model is then compared to existing body of knowledge in theoretical grounding in a rigor cycle, and back to the designers in the meta-relevance cycle.

The knowledge exchanges presented in Figure 2 also form the three-part grounding process: Theoretical, empirical and internal grounding [12]. Theoretical and empirical grounding occurs between the meta-artefact and the artefact design cycle, and internal grounding occurs in both artefact design cycles. 


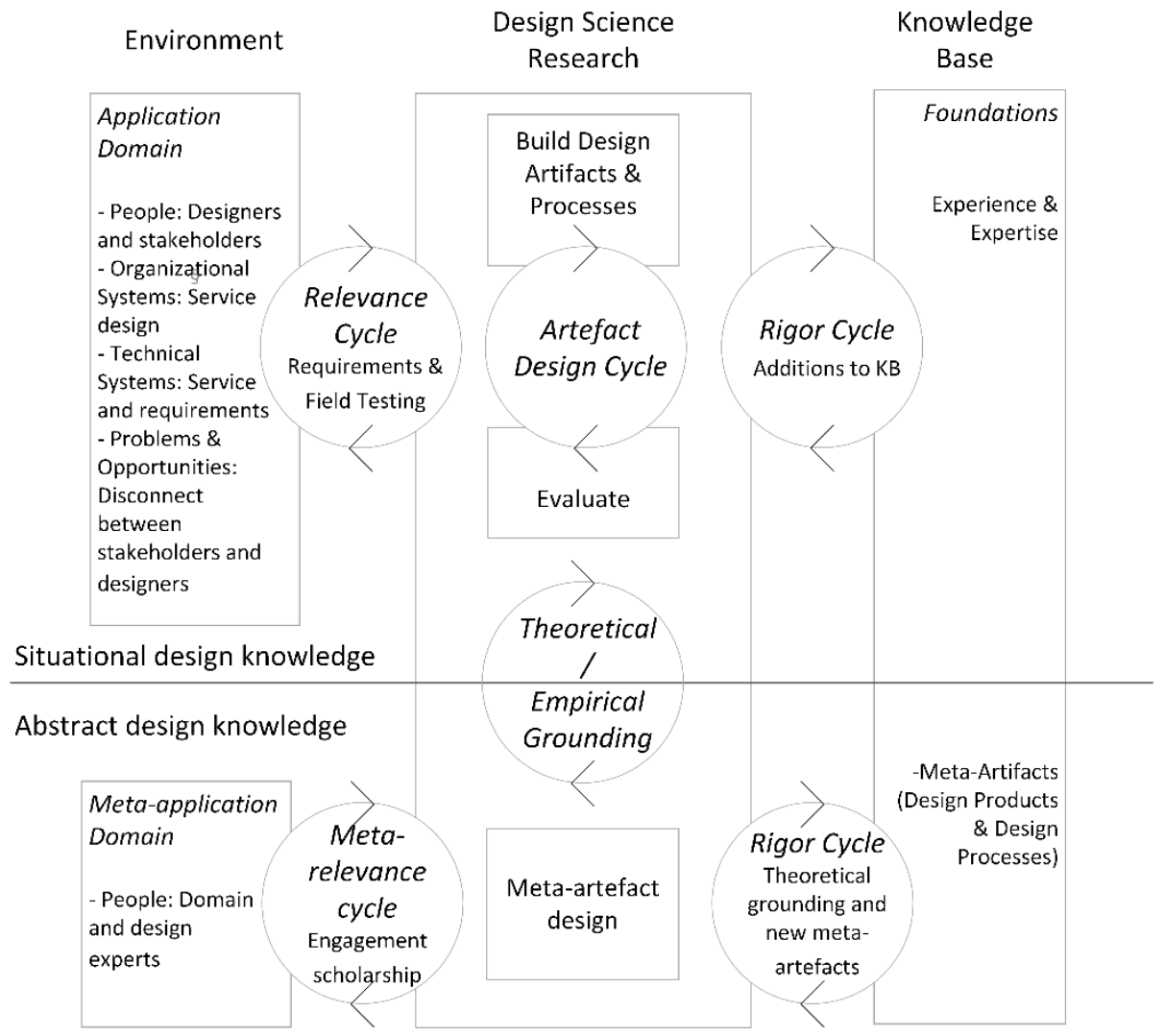

Fig. 2. Hevner's three cycle view [2] extended with the division to situational and abstract design knowledge [17]

\subsection{Evaluating and Grounding Abstract Design Knowledge}

As with all design science research, the validity of the artefact is judged by its utility [1]. The artefact resulting from meta-artefact design should be evaluated to establish its validity both before and after applying it to the artefact design cycle.

There are two levels of evaluation in design science research: artificial and naturalistic $[25,26]$. Artificial evaluation is contrived or non-real in some manner and may consist of simulations, field experiments or lab experiments. Naturalistic evaluation is full evaluation of the situational artefact in its intended environment, the application domain. Naturalistic evaluation may consist of methods such as case studies, survey studies or action research.

Artificial evaluation is more suitable for abstract design knowledge and naturalistic evaluation is more suitable for situational design knowledge [11, 12]. Goldkuhl and Lind presented a multi-grounding process for design science research [12], which was used by Ostrowski and Helfert [11] to extend Peffers's design science research process [22]. In this design process, newly created abstract design knowledge is first 
validated with artificial evaluation and then used to inform situational design. The output of the situational design is validated with naturalistic evaluation and abstract design knowledge is further validated by successful situational design after an empirical grounding process. The extended process is presented in Figure 3.

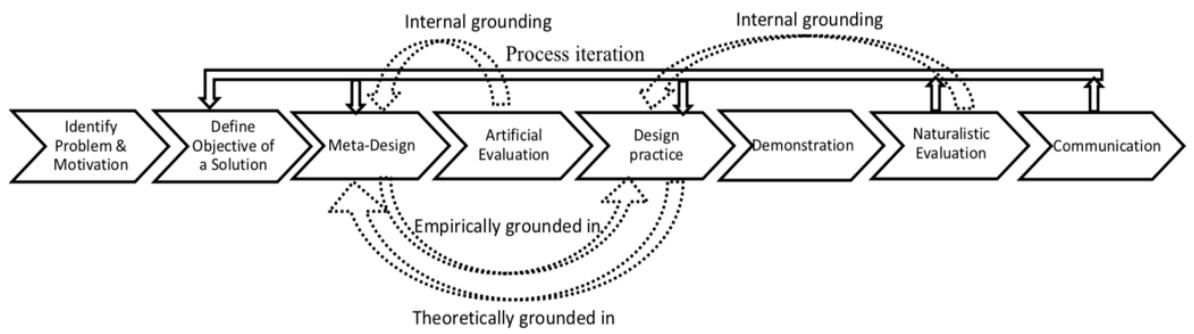

Fig. 3. Multi-grounding [12] applied by Ostrowski and Helfert [11] to the design science research process [22]

\section{Grounded Theory Research Method}

Grounded theory is a qualitative research method that seeks to develop theory that is grounded in systematically gathered and analyzed data [15]. It is a "an inductive, theory discovery methodology that allows the researcher to develop a theoretical account of the general features of a topic while simultaneously grounding the account in empirical observations or data" [27, p. 1]. Essentially, it can produce descriptive knowledge of novel situations or phenomena where no such knowledge yet exists. In information systems, grounded theory has been useful in developing context-based, process-oriented descriptions and explanations of information systems phenomena [15].

The objective of grounded theory is the discovery of a theoretically comprehensive explanation about phenomena, using techniques and analytical procedures that enable investigators to develop a theory that is significant, generalizable, reproducible and rigorous [28]. The aim of grounded theory is not only to describe a phenomenon, but also to provide an explanation of relevant conditions, how actors respond to the conditions and consequences of the actors' actions [15, 29]. For data analysis, it has a systematic set of procedures that support the development of theory that is inductively derived and continuously tested against empirical data through constant comparison [13]. The four principles of grounded theory research method have been summarized by Urquhart [15] as follows from the line of research performed Glaser and Strauss, first together [13] and then in divergent lines of research [30-32].

1. Main purpose of grounded theory is theory building.

2. Researchers should prevent prior knowledge of the field and preformulated hypotheses from hindering the emergence of ideas.

3. Analysis and conceptualization are engendered through the core process of joint data collection and constant comparison, where every slice of data is compared 
with all existing concepts and constructs. New knowledge from data is used to enrich an existing category, or to form a new category or relation.

4. "Slices of data," which can be of diverse types and from various sources, are selected in a process of theoretical sampling, where the researcher decides analytically the next source for sampling.

A key object in grounded theory is to aim for increasingly greater depth of analysis [13]. Urquhart et al. [15] have summarized three major steps in grounded theory research process following Glaser's approach to grounded theory [30], which are presented in Table 3.

Table 3. Three major phases of grounded theory research [15] with increasing depth of analysis

\begin{tabular}{|l|l|}
\hline $\begin{array}{l}\text { Grounded theory } \\
\text { research step }\end{array}$ & Summary \\
\hline $\begin{array}{l}\text { Open coding } \\
\text { (description) }\end{array}$ & $\begin{array}{l}\text { Describing conceptual constructs involved in the phenomenon and their } \\
\text { properties. }\end{array}$ \\
\hline $\begin{array}{l}\text { Selective coding } \\
\text { (interpretation) }\end{array}$ & $\begin{array}{l}\text { Defining and explaining the interactions between the conceptual con- } \\
\text { structs. Refining and generalizing. Understanding and explaining the } \\
\text { area under investigation. }\end{array}$ \\
\hline $\begin{array}{l}\text { Theoretical coding } \\
\text { (formulating a } \\
\text { theory) }\end{array}$ & $\begin{array}{l}\text { Formulation of a descriptive theory. Aim is to create inferential and/or } \\
\text { predictive statements about the phenomena. Achieved by defining rela- } \\
\text { tionships between individual interpretive constructs. E.g. associations, } \\
\text { influences or causal. }\end{array}$ \\
\hline
\end{tabular}

Just as in design science research, grounded theory has outputs that work towards increasingly abstract knowledge. Urquhart et al. [15] have defined three levels of theories by the level of abstraction: 1) narrow concepts, 2) substantive theories, and 3) formal theories. Substantive theories have been generated within a specific area of inquiry and are limited in scope. The highest level of abstraction is a "formal theory", which focuses on conceptual entities, such as organizational knowledge [31]. These levels are summarized in Table 4. One method to expand a grounded theory and contribute to the body of knowledge is to use theoretical generalization, which uses similar theories from the body of knowledge to expand the newly developed grounded theory [15].

Gregor [33] defines five types of theory in information systems research: analysis, explanation, prediction, explanation and prediction, and design and action. Urquhart et al. $[15$, p. 365$]$ suggest that "grounded theory has the capability to generate theory that exists in all these categories because it contains the essential building blocks of any theory - constructs in the form of categories and relationships between those constructs in the form of theoretical coding." However, we propose that the grounded theory is most suited for the first four, as grounded theory is most adept at analyzing constructs and explaining their relationships. By contrast, according to Gregor and Hevner [3], most abstract knowledge and theory created by design science research are of the fifth type, design and action. 
Table 4. Grounded theory output scopes [15]

\begin{tabular}{|l|l|}
\hline $\begin{array}{l}\text { Grounded } \\
\text { theory scope }\end{array}$ & Description \\
\hline $\begin{array}{l}\text { Bounded } \\
\text { context }\end{array}$ & $\begin{array}{l}\text { Narrow "seed" concepts, based on limited fieldwork and anecdotal evi- } \\
\text { dence. }\end{array}$ \\
\hline $\begin{array}{l}\text { Substantive } \\
\text { focus }\end{array}$ & $\begin{array}{l}\text { Generated through a rigorous application of grounded theory procedures. A } \\
\text { substantive theory extends its predictive and explanatory power to the spe- } \\
\text { cific set of phenomena from where it was developed. }\end{array}$ \\
\hline $\begin{array}{l}\text { Formal } \\
\text { concepts }\end{array}$ & $\begin{array}{l}\text { A formal theory that spans a set or family of several substantive areas. Ap- } \\
\text { plies to many kinds of situations, systems and organizations. Rare in scien- } \\
\text { tific literature. }\end{array}$ \\
\hline
\end{tabular}

\section{Creating Abstract Design Knowledge with Grounded Kernel Theories}

In this section, we present how descriptive knowledge created by the grounded theory research method [13] can be used as a kernel theory for design science research processes. Grounded theory can produce knowledge useful to design science research because a design science researcher is dependent on the descriptive knowledge base for descriptive and propositional knowledge that informs the research [3]. The better the situation and the phenomena involved are understood, the better it can be affected by the creation of novel artefacts.

We establish a connection between a grounded theory -based kernel theory and a design science process by using the DSR theory development framework created by Kuechler and Vaishnavi [6] to extend the meta-artefact creation process [9-11]. Our novel contribution is presenting an approach that specifically uses grounded theory for descriptive knowledge and demonstrating how it can contribute to the creation of any design science artefact, not only design theories. This approach builds on Ostrowski and Helfert's framework [8-11], Goldkuhl and Lind's division of abstract and situational design knowledge [12], and artificial and naturalistic evaluation processes in design science $[25,26]$. According to Gregor and Hevner [3, p. 343] "a design science research begins with an important opportunity, challenging problem, or insightful vision/conjecture for something innovative in the application environment." We propose that in order for the vision to be gained, the problem domain needs to be understood, and one method to understand the problem domain is to use grounded theory to generate an understanding of the phenomenon.

Our approach is most suited for situations where no previous descriptive understanding exists, or otherwise the researcher would obtain the required information from the existing body of knowledge. In Figure 4 we present an overview of the approach. It begins by using grounded theory to generate an initial grounded theory of the application domain, which becomes the grounded kernel theory in the artefact design process. This knowledge helps in the creation of the research goals and predicting the artefact's impact. Then the research team either creates a meta-artefact or obtains it from the existing body of knowledge to inform their artefact design. Finally, 
the created situational artefact solves an issue in the application domain. The application of the artefact also contributes feedback to the grounded kernel theory. As the application domain changes after introducing the artefact, the descriptive theory can be evaluated and improved in regard to the explanations and predictions it provides.

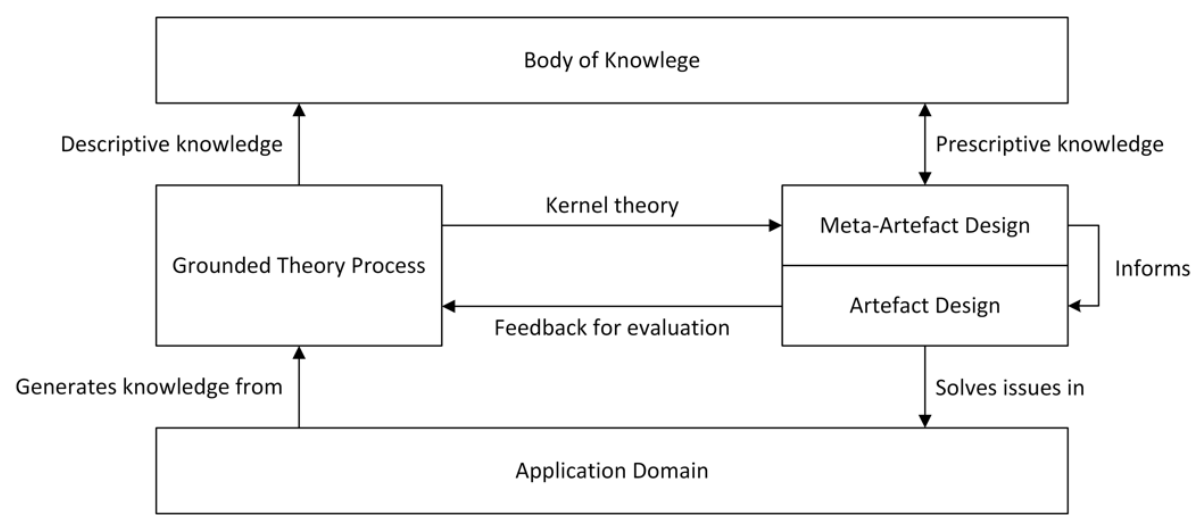

Fig. 4. The cycle of knowledge contributions between the descriptive grounded theory and design science knowledge processes

The exchange between descriptive and prescriptive, and abstract and situational contains feedback loops at every step, all of which were not detailed in Figure 4 for reasons of clarity. The artefact design process contributes abstract prescriptive knowledge to the body of knowledge, and the naturalistic evaluation that occurs in deploying the situational artefact to the application domain enables the validation of the meta-artefact following the multi-grounding principles [12]. These exchanges of information are detailed in the more detailed model presented in the next subsection.

\subsection{An Approach for Creating Abstract Design Knowledge with Grounded Kernel Theories}

Ostrowski's framework for creating abstract design knowledge as meta-artefacts for information systems recommends three steps for creating models for information systems: 1) Literature review, 2) collaboration with practitioners in engagement scholarship [34], and 3) then creating a solution model using one of the business modelling languages [8-10].

In this section, we present an approach that uses grounded theory [13] as defined by Urquhart et al. $[15,35]$ for information systems research to generate a kernel theory for a design science process. The grounded theory -based kernel theory enables understanding a phenomenon and creating abstract design knowledge based on that understanding. In our design, we follow the line of research that discusses and develops approaches for using descriptive knowledge as a basis for design theories [3, 5, 7, $23,28,36,37]$. This approach for creating kernel theories is valuable for situations that involve complex human factors, or for situations where there is an incomplete understanding of the phenomenon, the involved actors, and their relationships. The 
grounded theory method enables in-depth understanding of the problem by creating a situational, descriptive kernel theory that in turn informs the creation of the prescriptive artefact. As design science research problems are often complex problems that involve socio-technical systems [3] in complex interactions among subcomponents of the problem and its solution [1], in-depth understanding of the problem domain is valuable.

In Figure 5 we present a model of the entire process as synthesized from guidelines by Urquhart et al. $[15,35]$ for grounded theory in information systems research, a line of research on design theories $[3,5,7,12,23,36]$, and the design science process by Ostrowski and Helfert [8-11]. Our novel contribution to this model is an approach for using a kernel theory generated by the grounded theory method as an input in a design science process. Additionally, we present how the design science process can contribute back to the further development of grounded theory.

Grounding is essential in our approach to knowledge contributions. The grounded theory is grounded to the empirical data from the phenomenon (internal to step 1). Meta-design (step 4) is theoretically grounded to the kernel theory and empirically grounded in the naturalistic evaluation process (step 7). Eventually the situational design (step 6) produces enough evidence during naturalistic evaluation (step 7) to contribute new evidence to develop the grounded theory further ( $\operatorname{step} 9$ ).

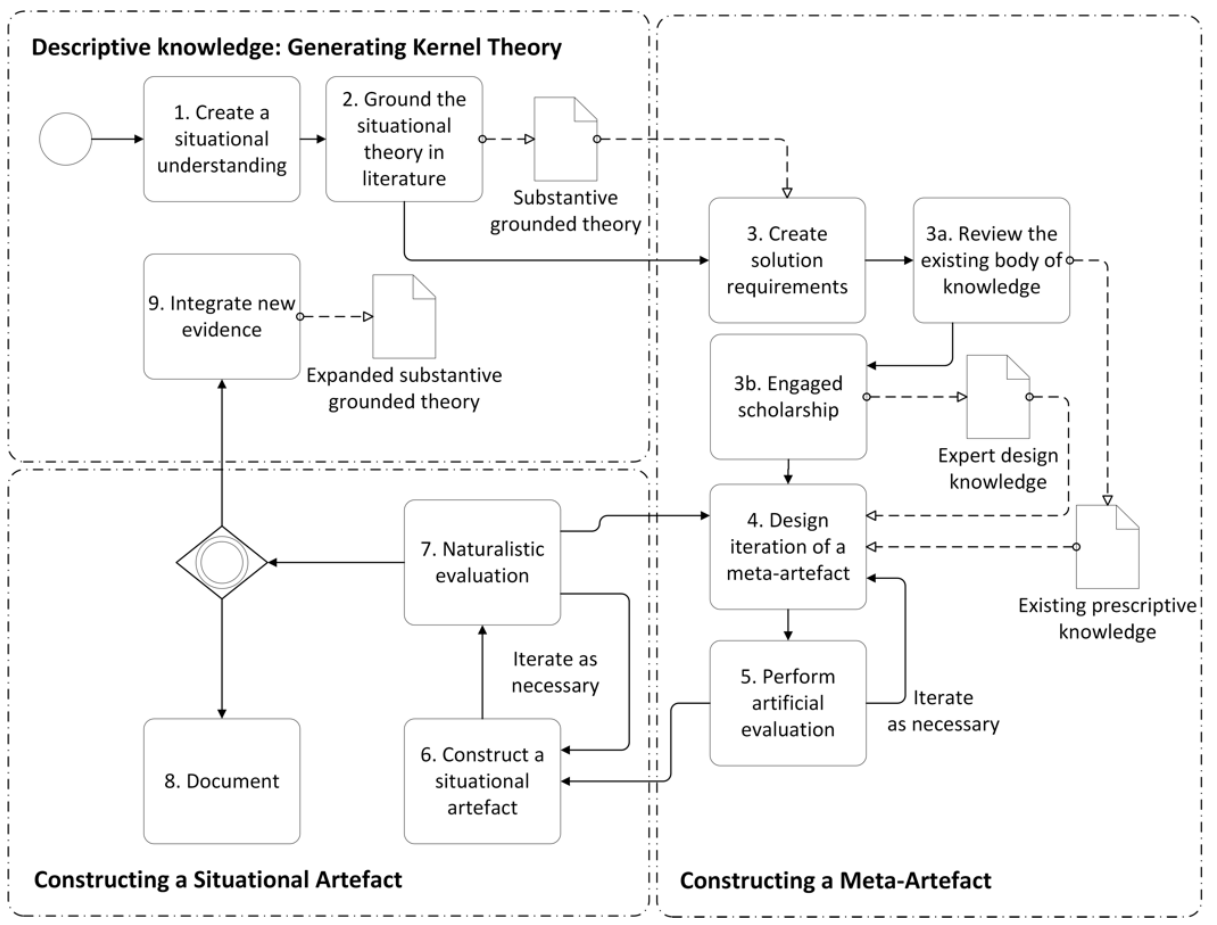

Fig. 5. Connecting grounded theory to design science research process with a kernel theory

We detail the steps presented in the model of Figure 5 in Table 5. 
Table 5. Steps for creating a kernel theory and using it to contribute to design science research

\begin{tabular}{|c|c|c|}
\hline Process step & Activities & Outputs \\
\hline $\begin{array}{l}\text { 1. Create a situa- } \\
\text { tional understand- } \\
\text { ing }\end{array}$ & $\begin{array}{l}\text { Using the three main steps of grounded theory to } \\
\text { generate a kernel theory that explains the phe- } \\
\text { nomenon, its constructs and their relationships. }\end{array}$ & $\begin{array}{l}\text { A substantive } \\
\text { grounded theory not } \\
\text { yet connected to } \\
\text { literature. }\end{array}$ \\
\hline $\begin{array}{l}\text { 2. Ground the } \\
\text { situational theory } \\
\text { in literature }\end{array}$ & $\begin{array}{l}\text { Comparing the grounded theory with the descrip- } \\
\text { tive body of knowledge and using existing } \\
\text { knowledge to scale it up. (Grounded theory does } \\
\text { not mandate a literature review, but it can be used } \\
\text { for theoretical integration after the initial research } \\
\text { [15]) }\end{array}$ & $\begin{array}{l}\text { Substantive ground- } \\
\text { ed theory that can be } \\
\text { used as a kernel } \\
\text { theory. }\end{array}$ \\
\hline $\begin{array}{l}\text { 3. Create solution } \\
\text { requirements }\end{array}$ & $\begin{array}{l}\text { Developing initial requirements for a solution } \\
\text { based on an understanding of the situation with } \\
\text { the help of the kernel theory. }\end{array}$ & $\begin{array}{l}\text { Research goals for } \\
\text { the design science } \\
\text { research process }\end{array}$ \\
\hline $\begin{array}{l}\text { 3a. Review the } \\
\text { existing body of } \\
\text { knowledge }\end{array}$ & $\begin{array}{l}\text { Finding existing prescriptive knowledge that can } \\
\text { assist in creating a solution. }\end{array}$ & $\begin{array}{l}\text { Existing prescriptive } \\
\text { knowledge and solu- } \\
\text { tions from the body } \\
\text { of knowledge }\end{array}$ \\
\hline $\begin{array}{l}\text { 3b. Engaged } \\
\text { scholarship }\end{array}$ & $\begin{array}{l}\text { Engaging design experts in evaluating solutions } \\
\text { and exploring the design space. }\end{array}$ & $\begin{array}{l}\text { Expert design } \\
\text { knowledge }\end{array}$ \\
\hline $\begin{array}{l}\text { 4. Design iteration } \\
\text { of a meta-artefact }\end{array}$ & $\begin{array}{l}\text { Designing a meta-artefact to inform the creation } \\
\text { of situational artefacts. }\end{array}$ & Meta-artefact \\
\hline $\begin{array}{l}\text { 5. Perform artifi- } \\
\text { cial evaluation }\end{array}$ & $\begin{array}{l}\text { Evaluating the meta-artefact e.g. with simula- } \\
\text { tions, lab experiments or field experiments. }\end{array}$ & $\begin{array}{l}\text { Evaluation results for } \\
\text { the meta-artefact }\end{array}$ \\
\hline $\begin{array}{l}\text { 6. Construct a } \\
\text { situational artefact }\end{array}$ & $\begin{array}{l}\text { Creating an artefact that addresses the issue in the } \\
\text { situation in the application domain. }\end{array}$ & Situational artefact \\
\hline $\begin{array}{l}\text { 7. Naturalistic } \\
\text { evaluation }\end{array}$ & $\begin{array}{l}\text { Empirical evaluation of the situational artefact in } \\
\text { the application domain. }\end{array}$ & $\begin{array}{l}\text { Evaluation results for } \\
\text { the situational arte- } \\
\text { fact }\end{array}$ \\
\hline 8. Document & Documenting and communicating the results. & $\begin{array}{l}\text { Prescriptive } \\
\text { knowledge contribu- } \\
\text { tion to the body of } \\
\text { knowledge }\end{array}$ \\
\hline $\begin{array}{l}\text { 9. Integrate new } \\
\text { evidence }\end{array}$ & $\begin{array}{l}\text { Developing the grounded theory further with new } \\
\text { data on the phenomenon. }\end{array}$ & $\begin{array}{l}\text { Expanded substan- } \\
\text { tive grounded theory }\end{array}$ \\
\hline
\end{tabular}

\subsection{Connecting Grounded Theory to Design Science Research Process as Kernel Theory}

The main tenet of the grounded theory method is developing new theory. However, common outputs in grounded theory research are substantive, explanatory theories instead of the grand theories which first come to mind when the word "theory" is mentioned. Design theories also have been called theories of the middle range [3], or by Merton [38, p. 39] "theories that lie between the minor and necessary working hypotheses that evolve in abundance during day-to-day research and the all-inclusive systematic efforts to develop a unified theory that will explain all the observed uniformities of social behavior, social organization, and social change." The descriptive 
middle-range theories created by the grounded theory are similar in scope to prescriptive design theories and can inform the creation of new abstract design knowledge.

A kernel theory is defined by Wallis et al. [39] as theories from natural sciences, social sciences or mathematics that are encompassed in design theory. Gregor and Jones [5] further define kernel theory to any descriptive theory that informs artefact construction, and Gregor and Hevner [3] present that a mature body of design knowledge should include a kernel theory. By contrast, we define justificatory knowledge to include any descriptive knowledge that informs design research [3]. Depending on how far the grounded theory research process advances towards abstract knowledge generation, it can create either. Bounded context or substantive focus combined selective coding can produce justificatory knowledge. Theoretical coding with substantive focus can generate grounded theories to be used as kernel theories. We relate these levels of grounded theory output scopes to inputs in design science research in Table 6. At all levels the knowledge created by grounded theory research can inform design science research processes by enabling a better understanding of the situation and the phenomena.

Table 6. Relating grounded theory outputs to design science research process inputs

\begin{tabular}{|l|l|l|}
\hline $\begin{array}{l}\text { Grounded theory re- } \\
\text { search step }\end{array}$ & $\begin{array}{l}\text { Grounded theory output } \\
\text { scope }\end{array}$ & $\begin{array}{l}\text { Use in design science } \\
\text { research }\end{array}$ \\
\hline Selective coding & $\begin{array}{l}\text { Bounded context or substan- } \\
\text { tive focus }\end{array}$ & Justificatory knowledge \\
\hline Theoretical coding & $\begin{array}{l}\text { Substantive focus or formal } \\
\text { concepts }\end{array}$ & Kernel theory \\
\hline
\end{tabular}

Kuechler and Vaishnavi [7] state that kernel theories can inform design science research and additionally design science research can in turn be refined and developed by the design science research process. They present an approach based on Venable [26] and Goldkuhl [23], where new empirical evidence created by naturalistic artefact evaluation allows evaluating the kernel theory. The new evidence as a form of descriptive knowledge can be confirmed by the kernel theory or lead to revision of the kernel theory [7]. A grounded theory research process can benefit from new empirical evidence created in a design science process, because constant comparison and evaluation of the theory against the data is one of the central principles in grounded theory.

\section{$5 \quad$ Evaluating the Approach for Creating Abstract Design Knowledge with Grounded Kernel Theories}

In this section, we evaluate our approach by using it to frame an existing design science research case. From a certain perspective, our approach can be considered a design science meta-artefact as well because it can be used to inform situational design, or actual research in this case. As a meta-artefact the most suitable evaluation method for our approach is artificial evaluation. We begin by summarizing an ongoing research case by Pourzolfaghar et al. to create meta-design artefacts to inform the 
creation of services in a smart city context. We begin with a brief definition of smart cities, how the ongoing research relates to smart services and the summarize the project's research goals. Then in the next subsection we relate their research design to the design science research approach presented in Sections 4 and 4.1. and present the evaluation results.

The definition for smart cities that Pourzolfaghar et al. use is that smart cities are innovative cities, which use ICT to improve quality of life for citizens [40-42]. According to Ferguson [43] services are the enablers in the digital cities and therefore, responsible to improve the citizens' quality of life. In other words, the services in the smart cities need to respond to the needs of the citizens. In this regard, Pourzolfaghar and Helfert [16] have defined the term 'smart service' for the services which meet the smart cities quality factors and respond to the smart cities stakeholders' concerns.

Pourzolfaghar et al. began their research project by identifying shortcomings in how currently smart city services were designed. This first step involved the researchers performing a series of interviews and producing descriptive knowledge about the current status of service design. From the discovery phase they proceeded to addressing the issue by developing a taxonomy for smart service elements which can be used to inform the design of smart services. This taxonomy is essentially a meta-artefact because it gives prescriptive knowledge towards creation of situational smart service artefacts, such as requirements or service instantiations.

\subsection{Framing the Research Case as a Process to Create a Meta-Artefact}

In this section, we frame the ongoing design science research project on smart city services using the approach presented in Sections 4 and 4.1. The Table 7 presents the project steps using a similar structure we used to introduce our approach in Table 5. Steps 1 to 4 of the research project have been completed at the time of publication, with step 5 ongoing. Steps 6 to 9 are planned as future work. 
Table 7. Framing the design science project by Pourzolfaghar et al. with our design science approach

\begin{tabular}{|c|c|c|}
\hline Process step & Activities & Outputs \\
\hline $\begin{array}{l}\text { 1. Create a situation- } \\
\text { al understanding }\end{array}$ & $\begin{array}{l}\text { Using a grounded theory -inspired } \\
\text { coding process to analyse the inter- } \\
\text { views on smart city service design. }\end{array}$ & $\begin{array}{l}\text { Initial justificatory } \\
\text { knowledge }\end{array}$ \\
\hline $\begin{array}{l}\text { 2. Ground the situa- } \\
\text { tional theory in } \\
\text { literature }\end{array}$ & $\begin{array}{l}\text { Performing a literature review on the } \\
\text { body of knowledge on smart cities. }\end{array}$ & $\begin{array}{l}\text { Kernel theory at bounded } \\
\text { context level }\end{array}$ \\
\hline $\begin{array}{l}\text { 3. Create solution } \\
\text { requirements }\end{array}$ & $\begin{array}{l}\text { Developing research goals for improv- } \\
\text { ing smart city service design process- } \\
\text { es. }\end{array}$ & $\begin{array}{l}\text { Research goal: Developing a } \\
\text { taxonomy to inform smart } \\
\text { service design processes }\end{array}$ \\
\hline $\begin{array}{l}\text { 3a. Review the exist- } \\
\text { ing body of } \\
\text { knowledge }\end{array}$ & $\begin{array}{l}\text { Finding existing prescriptive } \\
\text { knowledge that can assist in creating a } \\
\text { solution for service design. }\end{array}$ & $\begin{array}{l}\text { Selecting the TOGAF archi- } \\
\text { tecture vision development } \\
\text { template [44] }\end{array}$ \\
\hline $\begin{array}{l}\text { 3b. Engaged schol- } \\
\text { arship }\end{array}$ & $\begin{array}{l}\text { Engaging design experts at workshops } \\
\text { and conferences. }\end{array}$ & Expert design knowledge \\
\hline $\begin{array}{l}\text { 4. Design iteration of } \\
\text { a meta-artefact }\end{array}$ & $\begin{array}{l}\text { Designing first iteration of the taxon- } \\
\text { omy. }\end{array}$ & First version of the taxonomy \\
\hline $\begin{array}{l}\text { 5. Perform artificial } \\
\text { evaluation }\end{array}$ & $\begin{array}{l}\text { Presenting the taxonomy to practition- } \\
\text { ers and stakeholders and gaining feed- } \\
\text { back for the second iteration. }\end{array}$ & $\begin{array}{l}\text { Initial, non-systematic evalu- } \\
\text { ation for the meta-artefact. }\end{array}$ \\
\hline $\begin{array}{l}\text { 6. Construct a situa- } \\
\text { tional artefact }\end{array}$ & $\begin{array}{l}\text { Using the taxonomy to inform the } \\
\text { creation of artefacts related to smart } \\
\text { services. }\end{array}$ & $\begin{array}{l}\text { Smart service requirements } \\
\text { and instantiations }\end{array}$ \\
\hline $\begin{array}{l}\text { 7. Naturalistic eval- } \\
\text { uation }\end{array}$ & $\begin{array}{l}\text { Empirical evaluation of the situational } \\
\text { artefact in a smart city context. }\end{array}$ & $\begin{array}{l}\text { Evaluation results for the } \\
\text { situational artefact }\end{array}$ \\
\hline 8. Document & $\begin{array}{l}\text { Documenting and communicating the } \\
\text { results to practitioners, the application } \\
\text { domain, and the body of knowledge. }\end{array}$ & $\begin{array}{l}\text { Prescriptive knowledge con- } \\
\text { tribution to the stakeholders } \\
\text { and the body of knowledge }\end{array}$ \\
\hline $\begin{array}{l}\text { 9. Integrate new } \\
\text { evidence }\end{array}$ & $\begin{array}{l}\text { Developing the kernel theory further } \\
\text { with new data on the phenomenon. }\end{array}$ & $\begin{array}{l}\text { Expanded descriptive } \\
\text { knowledge }\end{array}$ \\
\hline
\end{tabular}

\subsection{Artificial Evaluation of the Approach for Creating Abstract Design Knowledge with Grounded Kernel Theories}

In this section, we evaluate the utility of our approach to connect kernel theories to design science research processes. We performed the evaluation by demonstrating the approach to the practitioners and then simulated the research project with the research group by using the steps presented in the previous subsection (Table 7). Evaluation data was gathered from the research group with interviews. This is an initial form of artificial evaluation [26], which should establish a preliminary utility of our approach [25], and thus first steps towards validity [1].

The members of the research group were interviewed first individually and then as a group. The research group agreed that the plan is beneficial, and the approach could inform their meta-artefact design process. While not a full proof of the framework's validity, it can be considered a promising initial evaluation and suggests that the eval- 
uation should proceed with further, empirical testing. The interview-based evaluation found the following benefits from the proposed approach.

- The design process involves complex problems in sociotechnical systems within multi-stakeholder environments. In this case, the proposed approach for gaining descriptive knowledge with grounded theory would be suitable.

- The approach brought knowledge exchanges into clearer focus for the research group and helped them to position the research project's descriptive knowledge contributions.

- The approach helped the research group to evaluate the role of justificatory knowledge and explicitly define the role of kernel theories in their meta-artefact design process.

\section{Conclusion}

In this paper, we presented an approach for using the grounded theory method to create kernel theories for design science processes. By introducing this approach, we explained and clarified the connection between descriptive and prescriptive knowledge. The processes that generate descriptive and prescriptive knowledge can sometimes be seen as mutually exclusive in research projects. Our main contribution is to clarify their relationships and demonstrate how both knowledge creation processes can be complementary to each other in design science research. Furthermore, we demonstrated the approach by using it to frame an ongoing research project in smart city service design.

Our contribution to the evolving body of knowledge of design science research is demonstrating how kernel theories generated with the grounded theory method can contribute to any artefact creation process, not only design theories. With this demonstrated approach we contribute to the Kuechler and Vaishnavi's theory generation framework [6], the line of research that discusses the use of descriptive knowledge in design science $[3,5,7,23,28,36,37]$, and the line of research in meta-artefact design by Ostrowski and Helfert [8-11].

The approach presented in this paper can be considered a design science metaartefact and we presented the first steps towards the its artificial validation. The approach requires further investigation and evaluation in order to establish its utility and thus the validity. If in the future a research project uses the approach with positive outcomes, that can be considered naturalistic evaluation and will eventually lead to the approach's full validation.

\section{Acknowledgements}

The work of the first author was supported by the Ulla Tuominen Foundation. This work was supported, in part, by Science Foundation Ireland grant 13/RC/2094 and cofunded under the European Regional Development Fund through the Southern \& 
Eastern Regional Operational Programme to Lero - the Irish Software Research Centre (www.lero.ie).

\section{References}

1. Hevner, A.R., March, S.T., Park, J., Ram, S.: Design science in information systems research. MIS Q. 28, 75-105 (2004).

2. Hevner, A.R.: The three cycle view of design science research. Scandinavian Journal of Information Systems. 19, 87 (2007).

3. Gregor, S., Hevner, A.R.: Positioning and presenting design science research for maximum impact. MIS quarterly. 37, 337-355 (2013).

4. Iivari, J.: A paradigmatic analysis of information systems as a design science. Scandinavian journal of information systems. 19, 5 (2007).

5. Gregor, S., Jones, D.: The anatomy of a design theory. Journal of the Association for Information Systems. 8, 312 (2007).

6. Kuechler, W., Vaishnavi, V.: A framework for theory development in design science research: multiple perspectives. Journal of the Association for Information systems. 13, 395 (2012).

7. Kuechler, B., Vaishnavi, V.: On theory development in design science research: anatomy of a research project. European Journal of Information Systems. 17, 489-504 (2008).

8. Ostrowski, L., Helfert, M.: Business Process Modelling in Design Science Paradigm. In: SpringerLink. pp. 111-122. Springer, Cham (2013).

9. Ostrowski, Ł., Helfert, M., Hossain, F.: A Conceptual Framework for Design Science Research. In: Perspectives in Business Informatics Research. pp. 345-354. Springer, Berlin, Heidelberg (2011).

10. Ostrowski, L., Helfert, M.: Reference Model in Design Science Research to Gather and Model Information. AMCIS 2012 Proceedings. (2012).

11. Ostrowski, L., Helfert, M., Xie, S.: A Conceptual Framework to Construct an Artefact for Meta-Abstract Design Knowledge in Design Science Research. In: 2012 45th Hawaii International Conference on System Sciences. pp. 4074-4081 (2012).

12. Goldkuhl, G., Lind, M.: A multi-grounded design research process. In: International Conference on Design Science Research in Information Systems. pp. 45-60. Springer (2010).

13. Glaser, B., Strauss, A.L.: The discovery of grounded theory: Strategies for qualitative research. Aldine, Chicago (1967).

14. Corbin, J.M., Strauss, A.: Grounded theory research: Procedures, canons, and evaluative criteria. Qualitative sociology. 13, 3-21 (1990).

15. Urquhart, C., Lehmann, H., Myers, M.D.: Putting the 'theory'back into grounded theory: guidelines for grounded theory studies in information systems. Information systems journal. 20, 357-381 (2010).

16. Pourzolfaghar, Z., Helfert, M.: Taxonomy of Smart Elements for Designing Effective Services. AMCIS 2017 Proceedings. (2017).

17. Knutas, A., Pourzolfaghar, Z., Helfert, M.: A meta-level design science process for integrating stakeholder needs. In: Proceedings of the International Conference on Computer-Human 
Interaction Research and Applications. Scitepress - Science and Technology Publications, Funchal, Madeira, Portugal (2017).

18. Hevner, A., Chatterjee, S.: Design Research in Information Systems. Springer US, Boston, MA (2010).

19. Lee, A.S.: MIS quarterly's editorial policies and practices. Mis Quarterly. 25, iii-vii (2001).

20. Simon, H.A.: The sciences of the artificial. MIT press (1996).

21. Cross, N.: Design/science/research: developing a discipline. In: Fifth Asian Design Conference: International Symposium on Design Science, Su Jeong Dang Printing Company, Seoul, Korea (2001).

22. Peffers, K., Tuunanen, T., Rothenberger, M.A., Chatterjee, S.: A design science research methodology for information systems research. Journal of Management Information Systems. 24, 45-77 (2007).

23. Goldkuhl, G.: Design theories in information systems-a need for multi-grounding. JITTA: Journal of Information Technology Theory and Application. 6, 59 (2004).

24. Sun, Y., Kantor, P.B.: Cross-Evaluation: A new model for information system evaluation. Journal of the American Society for Information Science and Technology. 57, 614-628 (2006).

25. Pries-Heje, J., Baskerville, R., Venable, J.: Strategies for design science research evaluation. ECIS 2008 proceedings. 1-12 (2008).

26. Venable, J.: A framework for design science research activities. In: Emerging Trends and Challenges in Information Technology Management: Proceedings of the 2006 Information Resource Management Association Conference. pp. 184-187. Idea Group Publishing (2006).

27. Martin, P.Y., Turner, B.A.: Grounded theory and organizational research. The journal of applied behavioral science. 22, 141-157 (1986).

28. Adams, L.A., Courtney, J.F.: Achieving relevance in IS research via the DAGS framework. In: System Sciences, 2004. Proceedings of the 37th Annual Hawaii International Conference on. pp. 10-pp. IEEE (2004).

29. Kinnunen, P., Simon, B.: Building Theory About Computing Education Phenomena: A Discussion of Grounded Theory. In: Proceedings of the 10th Koli Calling International Conference on Computing Education Research. pp. 37-42. ACM, New York, NY, USA (2010).

30. Glaser, B.G.: Theoretical sensitivity: Advances in the methodology of grounded theory. Sociology $\operatorname{Pr}(1978)$

31. Strauss, A.L.: Qualitative analysis for social scientists. Cambridge University Press (1987).

32. Strauss, A., Corbin, J.M.: Basics of qualitative research: Grounded theory procedures and techniques. Sage Publications, Inc, Thousand Oaks, CA, US (1990).

33. Gregor, S.: The nature of theory in information systems. MIS quarterly. 611-642 (2006).

34. Van de Ven, A.H.: Engaged scholarship: A guide for organizational and social research. Oxford University Press on Demand (2007).

35. Urquhart, C.: Grounded Theory for Qualitative Research: A Practical Guide. SAGE (2012).

36. Gregory, R.W.: Design science research and the grounded theory method: Characteristics, differences, and complementary uses. Theory-guided modeling and empiricism in information systems research. 111-127 (2011). 
37. Holmström, J., Ketokivi, M., Hameri, A.-P.: Bridging practice and theory: A design science approach. Decision Sciences. 40, 65-87 (2009).

38. Merton, R.K.: Social theory and social structure. Simon and Schuster (1968).

39. Walls, J.G., Widmeyer, G.R., El Sawy, O.A.: Building an information system design theory for vigilant EIS. Information systems research. 3, 36-59 (1992).

40. Anthopoulos, L., Janssen, M., Weerakkody, V.: A Unified Smart City Model (USCM) for smart city conceptualization and benchmarking. International Journal of Electronic Government Research (IJEGR). 12, 77-93 (2016).

41. Booch, G.: Enterprise architecture and technical architecture. IEEE software. 27, (2010).

42. Kondepudi, S.N., others: Smart Sustainable Cities Analysis of Definitions. The ITU-T Focus Group for Smart Sustainable Cities. (2014).

43. Ferguson, D., Sairamesh, J., Feldman, S.: Open frameworks for information cities. Communications of the ACM. 47, 45-49 (2004).

44. Weisman, R.: An Overview of TOGAF Version 9.1. Publ. by Open Gr. 43 (2011). 